\title{
$[1]$
}

\section{The Fishing Day}

It is six A.M. Charlie wakes up to morning sun and rising heat. He'd like to roll over and go back to sleep, but last night's red sky and the radio weatherman told him today's going to be hot. If he doesn't get moving, he'll soon pay for it. He grabs a cigarette from a pack on his night table. A couple of drags, and he pitches out of bed. He reaches for the work clothes he shucked off last night in a heap by the door so the fish smell won't spread. Dungarees and hip boots are all he'll need today, but he puts on a T-shirt too.

Down in the kitchen his black Labrador, Bullitt, lies by the refrigerator. Charlie pours himself a glass of milk and dumps a little in the dog's dish. He grabs his water bottle from the refrigerator. Cramming down a doughnut in two bites and clamping a second one in his teeth, he takes his cap from a nail in the wall and kicks open the screen door. Bullitt tries to edge out after him, but he knees him back inside. He would love to take the dog along, but with Bullitt nosing among the crabs and getting pinched he knows it would take him twice as long to finish.

Outside a fine mist is quickly evaporating but clings to the swamp in shallow clouds. It is hot in the sun, cold in the shade, clammy everywhere. Charlie puts his water bottle under the front seat and starts his pickup. He backs up to his workshed door. A thick swarm of yellow flies and mosquitoes attacks him as he gets out of the truck. With the engine running, he loads up his bait baskets. This morning he has frozen fat backs, and they're a poor bait fish. He'd rather have fresh spots and croakers, but he was late getting to the bait dealer last night and had to take what was left. What's worse, he could get only four bushels, and that may not be enough. He'll have to get there earlier 
today. Poor bait means poor crabbing. He loads the rest of his equipment: crab boxes, poling oar, and spare crab pot. He reaches in the back for the gas can and shakes it a couple of times to be double sure it has enough in it for the day. Then he climbs back in the cab and starts off down the dirt track.

Charlie drives over high ground to the drainage ditch where he built his dock last summer-duckboards laid on marshy ground, and extended on pilings a little way into the ditch. His skiff is tied to one of the pilings. He hauls all of his gear off his truck and down to the water's edge. Last week he was in a hurry to get going and stepped off the boards carrying a full bait basket. Up to his thighs in the marsh, scrambling, he'd managed to get out before he sank. Today he walks down the middle of the boards.

Before loading up he quickly scoops with a cut bleach bottle at the half-inch of brownish-green water in the skiffs stern. Then he puts the empty crab boxes in the bows and the bait boxes toward the stern. A flat-bottomed skiff rides better under power if it is trimmed light in the bows. He hooks up the gas can to the motor, slings the spare crab pot on top of the bait, drops the poling oar down by the washboards, and makes one last trip back to the truck. He pulls open the hood, flips off the battery cables, which are loose, and eases the battery out of its cradle. He carries it to the skiff and connects it to the motor. It would be nice to have two different batteries, but you can't drive two things at once.

Charlie slips the bowline off the piling, stows it inboard, and grabs the poling oar. Here in the ditch by the dock the water is too shallow for the motor. Standing in the stern he digs the blade of the poling oar into the mud and gives a gentle shove. The trick is to push just hard enough to get going but not so hard that the pole sticks in the mud. The skiff glides softly, steadily forward ahead of his strokes.

A few hundred yards and the ditch runs into a small navigation canal. Charlie stops poling and drops the outboard propeller into the water. He squeezes the rubber bulb on the gas feed line a few times to prime the engine, adjusts the choke, and pulls the starter cord. There is no sign of life, but Charlie didn't seriously expect there to be on the first try. Still, after five or six tugs there's only a sputter. He gets impatient. He gives three hard, fast pulls. On the final go the engine catches and dies. He wrenches the cord once more. The engine roars. A plume of oily blue exhaust hangs over the water and mingles with the morning mist.

He lights a cigarette and settles down on the stern transom for the 
chug up the canal. He'd like to rip along at full throttle, but he can't afford the speeding fine. Instead he putters, mostly staring ahead, sometimes looking into the swamp if something catches his eye. There is no breeze. Wisps of mist curl over the swamp grasses growing thick to the horizon. At the canal's edge herons dabble in the waterlilies, stopping to peer into the water or up at Charlie as he cruises by, ripples from his bow slapping the banks.

Suddenly the canal widens and dumps out into a large, open, brackish sound. Immediately Charlie throws the throttle wide open. The bow rises out of the water, and the skiff bumps and crashes along at full speed. He makes straight for the point on the distant opposite shore which is his landmark for navigation. It is a little rise, about halfway between an abandoned coast guard station and a lighthouse. Somewhere between the canal's mouth and that point is his line of pots. Navigating out here is always a bit hit-or-miss, but as long as there isn't any fog around, there are enough shore points to get your bearings by. There is no wind, the water is flat, so he makes good time. In fifteen minutes he spots his first float almost dead ahead.

Charlie cuts the throttle. With the engine idling he glides up to the first pot. Now is his time to get all gear set for smooth fishing so he can be home for lunch. He lifts a crab box to the skiff s middle transom and opens a bait basket at his feet. Bad luck. The fish have not thawed overnight. He'll have a tough time eking them out. In hopes the sun will work on the frozen fish he opens all of the baskets and does what he can to pull apart the hunks of bait. The extra work makes him sweat. He strips off his T-shirt and stuffs it in a locker under his feet. He drags out a pair of thick rubber gloves to protect his hands from the combination of water, crab claws, pot netting, and frozen fish. He pulls the spare pot toward him and begins his routine.

A crab pot is a wire-mesh box with a hinged lid that fastens with a catch. Two of the sides have funnels leading in. At the bottom is the bait trap, a wire cage closed with a rubber plug. A waterproof line about five feet long hangs from the frame of the cage. The float attached to the line's free end is marked with the owner's name. Charlie likes to use bleach bottles for floats. They are strong and show up well from a distance. He marks them with a big C S, his initials, in waterproof marker. Because crabbers are always begging them, bleach bottles are not easy to come by, so a few of his floats are milk jugs. But these break easily and have to be replaced all the time.

Charlie flips the spare pot over, jerks the plug from the bait trap, reaches between his legs for a handful of bait, stuffs it into the basket, 
jams the plug back. With the pot in his right hand and the float in his left, he flings the whole contraption into the water. Then he stoops to grab the float line that will haul in his first pot of the day. Five or six blue crabs scuttle along the sides and bottom of the pot. Not good, not bad. The pots will have to average more than that for him to make money on the day. This end of the line is often thin, though, so Charlie is not too worried. He pulls the plug and lets the old bait drop over the side. He opens the pot and knocks the crabs out into the crab box, reaches in and pulls loose a crab that will not shake free. He sets the pot upside down in front of him, baits it, and gives a burst on the throttle to move the boat along to the next pot, several boat lengths ahead. As he gets near it, he tosses out the baited pot and hauls up the new one.

When the whole operation is running well Charlie can cast out, haul in, empty, bait, and move on in about two minutes. Today it may take him closer to three because of the frozen bait. Since he has a hundred pots to tend, he could be on the water an hour and a half longer than usual. That means he will be late to the bait dealer again. He thinks about rushing the job along to make up time but immediately decides against it. Changing your work pattern leads to mistakes, and mistakes out here can be fatal. Two of Charlie's uncles drowned in the sound, and he has had enough near-misses to respect the water. So he visits each pot at his normal pace.

Charlie doesn't pay much attention to the world around him when he is working his pots. The regularity of the task combined with the stillness of the day are relaxing and gently mesmerizing. Three hours into the job things have begun to pick up a little. The sun, which is now scorching hot, has softened the frozen fish, making it much easier to handle. It looks like the catch will be moderate to decent. He has filled two boxes and part of a third. If it holds up at this rate, he will at least come out ahead of his costs. But the bait situation is still not good. Because the frozen fish was hard to break up at the outset, he has used too much and may run out before the end of the job. He is part way into the third bushel with fifty pots to go.

At this point in the line Charlie sees a string of floats running beside his own. These are eel pots set by a neighbor. He does not mind having eel pots close by. They do no harm to the crabbing, some people even say they are good luck, and a few times a week he runs into his friend and stops to chat for five or ten minutes. Also, with two people working the area unwanted visitors can be kept out better. If 
they had been crab pots, there would be trouble. It is hard enough to make a living at crabbing without someone horning in on your territory. When that happens float lines get cut, pots are robbed, and men start carrying guns in their boats. No one has tried to move in lately, but the fishing has been generally good so far this season. Still, another month may bring short hauls, and everyone will have to look out.

Charlie starts baiting the pots light, but he is worried. The fat backs are poor bait to begin with and only do a halfway decent job if they are piled into the bait basket. Thin bait leads to poor crabbing: a lot of hard work and no money to show for it. But the choice is to bait regular until he runs out and leave the last string empty or bait thin and spread the losses. He thinks the catch will be about even whichever way he does it but chooses to bait thin because he cannot stand to throw out unbaited pots.

The rest of the work goes along pretty fast, partly because baiting takes less time than before and partly because the catch is poor in places. Several pots are empty. Even with careful measuring the bait looks as if it will give out toward the end. Charlie thins the bait out more and more until he has three fish left. He puts one in each of the next three pots and moves on down the line. When the bait gives out there are only two floats in front of him, so things are not so bad. He dumps the last baited pot and hauls in. There is a tiny bit of yesterday's bait in the basket; he leaves it in and dumps out the two crabs inside. He moves on to the last float, tosses out the partly baited pot, and hauls in the remaining one. It has no bait left in it and no crabs. Charlie takes this pot and rests it in the stern, then rearranges his gear for the ride home. He stacks the empty bait baskets inside one another and pushes them in the bow, wedging them in place with the spare crab pot. Then he lifts the filled crab boxes into the stern. He has just about filled four. He stacks them two on two and sticks the fifth, empty one in front of the pile. He pulls off his gloves, puts them in the locker. He takes out his water bottle and has a long drink. Next, he puts on his T-shirt, finds his cigarettes where they have been bunched up in the sleeve, lights up, and races the motor for the ride home.

At the beginning of the journey back Charlie stands up in the stern of the boat, slightly stooped because he is tall and the throttle is low. The filled crab boxes block the flow of air, and he wants the wind and spray to cool him off. The sun is directly overhead, but the breeze from the boat's headway is pleasant. After a few minutes he sits down 
so he can go faster. It feels stuffy back there, but he resists the urge to keep standing up. It will slow him down too much, and he is already late.

Back at the dock it is hot and sticky. The flies swarm around as soon as the boat pulls in. Without getting out of the skiff Charlie piles his gear on the dock. Most of the crabs slowly jostle around in the boxes, but a few quicker ones have crawled out and flopped into the bottom of the boat. He scoops them up with his bailing jug and throws them back into the blue, clacking mass. He lumbers up the duckboards with the boxes, one at a time: they weigh maybe a hundred pounds apiece. He loads the boxes on the tailgate of his truck and piles everything else helter-skelter in the truck bed. He shuts off the gas valve to the outboard and disconnects the gas can, which he stores beside the spare tire behind the cab. Finally, he disconnects the battery and reinstalls it in the truck.

Charlie drives back to the house. Even at its slowest speed, the truck sways and lurches along the deeply rutted track. He backs up to his work table beside the shed, cuts the motor, and goes into the house. The kitchen clock says 1:30. He is over an hour later than usual. Bullitt leaps around him, butting him, so Charlie bends down and rubs his head fiercely. He searches in the cupboard for a can of potted meat and a package of Nabs crackers and takes the last can of beer from the refrigerator. It is too hot to eat inside, and anyway he hates to be cooped up indoors. So he walks down to the pecan tree in the side yard with Bullitt running beside him and sits down to eat in an old battered aluminum folding chair. He flips up the ring pull top of the lunch meat, rips open the Nabs packet with his teeth, and uses the crackers to shovel the meat out of the can. Ten minutes later he is finished. He tosses the last bite of cracker to Bullitt and then pops the top on his beer and takes a sip. He lights a cigarette, picks up the beer can, and walks over to the work table where he pitches the trash into a bucket. From the shed he collects a pile of bushel baskets and lids, and brings them to the table.

The work table is about five foot square with plywood sides rising eight inches above its surface to form a wide, shallow trough. In the center are two pairs of work gloves, one canvas, the other rubber. Charlie puts on the canvas gloves first, and over them the rubber ones. Then, protected against pincers, he dumps the crabs from the boxes onto the table. They cascade in a blue/white shower and settle in a scuttling, tumbling mass. Flies whiz and swirl over them, some 
landing on Charlie's arms. He slaps at them sporadically as he starts to grade the crabs.

He spreads two bushel baskets at his feet, one on the left for females and the other on the right for "jimmys," with a spare crab box at the side for those that are too small for sale. Charlie sorts mostly by eye. He pulls out one or two at a time and pitches them right or left according to sex. Every tenth one or so is too close to call, so he fits its body between slots he has cut in the plywood sides of the table. There are two slots: five inches wide for females and six inches for males. If the points on the body slip into the slots the crabs are too small and wind up in the crab box.

Today he checks some he usually would toss down unmeasured. The fish dealer has been giving him a hard time lately about making up baskets with undersize crabs. Charlie knows there haven't been any small crabs in his loads. The dealer is probably just using that as an excuse to stop buying from him for the season or cut the price. The crabbing has opened up in Maryland, and Northern buyers are not coming South as often. That means only the local trade is left, and there is not enough of that to keep everyone in business. The eeling season lasts longer, but Charlie can't bring himself to fish for eelsnasty, slimy things that remind him of snakes. Also, he would have to deal direct with Yankee buyers, and he doesn't want to do that if he can help it. Anyway, who would want to eat eels except some damn Yankee? He has heard somewhere that they are shipped to Europe, and Charlie believes it. They eat all kinds of crazy things over there.

The grading takes ninety minutes. He has just about seven bushel baskets full and half a box of smalls. He wires the basket lids down tight. Then he takes off his two pairs of gloves and spreads them out in the middle of the empty table. He rummages above the dashboard of his truck for a black felt-tip to mark the basket lids with a big F or J and his own initials underneath. He loads the crabs on his truck and stores his empty boxes along with his poling oar in the shed. He opens the passenger door and Bullitt, who has been grubbing around in the bushes after chipmunks, races to jump in. Charlie climbs in beside him and turns the engine over. They make off down the swamp road toward Tidewater; Charlie lights a cigarette, and Bullitt sits up straight as he can, staring ahead through the windshield.

The five-mile swamp road is absolutely straight to the horizon, and on either side are drainage ditches formed when they threw up mounds of mud in the center to build the road on. The road is about 
forty years old. Charlie remembers when coming this way meant taking the corduroy road-a floating road of lashed logs, built before they had equipment to dig the swamps. Now the road is smooth and fast. On either side swamp grasses sway as the truck passes. Otherwise all is still in every direction.

Instead of turning left down to Tate's Point where the fish dealer is, Charlie turns right and swings onto a dirt drive. He stops at the house at the end and honks the horn. After a few minutes he honks again, and his nephew Gerry walks slowly out and gets in beside Bullitt. Charlie has promised his younger sister he will help her son get started crabbing. Today he wants him along to look at some equipment for sale down at Martin's Point. Gerry has one or two pots he has fished since he was fourteen, and his father has given him a few old ones he used to use before he took a factory job. Now that Gerry has finished high school and can begin a full day's work, these are not enough. He has been guiding for bass fishermen in the sound for most of the spring and early summer, so he has a little saved to buy pots. Charlie may end up lending him the rest if the price is too high.

Next stop is a big green house back on the main road. A friend of Charlie's mother lives here, and he has been meaning for several days to stop by and see if she wants some crabs. Charlie leaves the engine running and goes to the back screen door and hollers. He hears a shout from the inside and walks in. Florence is sitting at the kitchen table peeling potatoes. The aluminum pots bubbling on the stove fill the air with thick steamy smells: a blend of greens, cornmeal, and pork fat. She is a widow and lives alone, but she always cooks the evening meal for her two daughters and their families. She is known as a good cook, never turns anyone away at mealtimes, and always has plenty to go around, with some to spare for a quick lunch the next day.

Charlie stands just inside the door shuffling his feet. "Hello, Miss Florence, how're you making out today?"

"Oh, hello, Charlie. All right, I guess. Can't complain."

"Well, I've got some small crabs on the truck I can let you have if you want 'em. I'll be glad to give you however many you want."

She grins wide. "Thank you kindly. A half a bushel'll do me just fine, and if you don't mind, could you just leave 'em outside in the shade 'til I can get to 'em." She gives him a big steamer pot to put them in and thanks him again.

Just before he leaves, Charlie hesitates. "Miss Florence, would you happen to have any spare bleach bottles around?" 
"Well, I'm about finished with one, so if you care to come around next Monday, I can let you have it then."

He says he'll do that. Out in the yard he tips a bunch of crabs from the box into the steamer. He leaves the pot under a mimosa tree by the kitchen door and climbs into the truck.

Back on the main road to Tate's Point, Charlie explains to Gerry about the equipment they are going to see. Charlie doesn't know the man very well. He heard from the fish dealer he's about ready to quit fishing and take a factory job. His sons don't want to take up the business. Rather than watch good equipment rot, he'll let it go. Charlie is sure it is all decent gear. Mostly it is a question of what he wants for it and how much he is willing to bargain.

It is twenty miles from Tidewater to Tate's Point, through small towns and open farmland. The fields are several feet below the road and are cut into large squares by deep drainage ditches. The soil is a rich, loamy brown. Most of the fields have soybeans in them, already looking green and bushy, and the rest are planted in corn. Every once in a while the neatly drilled rows are interrupted by clusters of gravestones on land rises. Each of the towns they pass through is little more than a clump of a dozen houses or so, a church, and a general store. One has a bank, another has a diner, and a third has a garage. New businesses are dotted in isolation among the farm lands: a supermarket, a realtor, an ice-cream stand. As they get nearer to Tate's Point the land to the left gets swampy. Through breaks in the trees the sound appears. Before long the road is hugged up against the shore of the sound. Charlie stops at a small dirt turn-around by the sound and goes to the back of the truck to get what is left of the box of smalls. He takes them down to the water's edge and pitches them in.

Smith's Fish Market is a long, narrow, whitewashed cement block building on the edge of town. Charlie backs the truck up to a door in the back, at one end. He makes Bullitt wait in the cab while he and Gerry unload and weigh the crabs. Charlie pulls on the long sprung door handle, and the heavy, foot-thick door swings open. Inside it is chill and very dark. Charlie flips on the sixty-watt naked bulb hanging from the middle of the ceiling. He wheels a large balance-beam scale out from the wall to near the door, and he and Gerry stack four bushel baskets on the metal weighing stand. Charlie slides the counterweight on the balance beam along to the $200-\mathrm{lb}$. marker. It does not move. He edges it several notches, but still it does not move. Several more, and it falls down with a clang. He pushes it back one notch, then, 
another. The beam hangs poised for a second, then falls softly down: 216 lbs. Charlie and Gerry stack the baskets against the wall. The remaining three baskets balance out at $148 \mathrm{lbs}$. They stack the three baskets by the other four and return the scale to its place. Charlie pulls a clip board from a nail by the door and on the top sheet at the bottom of a list of names writes his own name, calculates the total in the margin, doublechecks his figuring, and then writes down 364 lbs. beside his name.

Charlie and Gerry walk around the side of the building to a small storefront and walk in. A bell tinkles from the top of the door and Sam Smith, who is arranging fish filets in a refrigerated cabinet lined with shaved ice, looks up to see who has come in. He finishes stacking the fish and wipes his hands on a towel. Charlie tells Sam he has brought in $364 \mathrm{lbs}$. of crabs. Sam pulls a calculating machine toward him and punches a few buttons, then takes an invoice pad from the counter and draws up a receipt. He gives the carbon copy to Charlie, and as he hands it to him says he hopes they are all good-sized ones. Charlie says nothing and jams the receipt in his T-shirt pocket. Before leaving he introduces Gerry to Sam and tells him he is planning to take up crabbing soon. Sam nods and tells him to come by when he has some crabs to sell.

Back in the truck Charlie starts the engine and pulls the receipt from his pocket. It says: “364 lbs. crabs@ @ 25c. Total \$91.” Things could be worse. The price is holding at about its best, and seven bushels is a moderate catch. But he can't expect the price to hold for too much longer. Before July is out Sam will probably be paying twenty cents, and by mid-August he could be down to fifteen. At that price it doesn't pay to go out, so the more he can make now while the price holds, the better. Still, it is hard to save much out of ninety-one dollars. Charlie clips the receipt to a wad of others fastened to a clip on the back of his sun visor, on the left-hand side, and throws the truck in gear. He will settle up with Sam at the end of the week.

Charlie turns left on the main road back to Tidewater but almost immediately pulls off at a house to the right. Charlie and Gerry get out, and this time Bullitt jumps out too and follows them down a rutted dirt track leading to a dock on the sound. At the dock two men are stacking eel and crab pots. Charlie recognizes Jo Midgett, the one who is selling the pots, but does not know the man with him.

"Hi, how're you doing?" says Charlie.

Jo spits into the water. "All right," he says. "How're you?"

"I hear you've got some pots for sale. Mind if we take a look?" 
Jo shows him around several stacks of gear: a haul seine net, ten gill nets, eighty crab pots, and thirty eel pots. Charlie looks at each piece but doesn't say much. Gerry follows after him turning some of the nets over, looking at the pots. All of the equipment is in good shape. The nets don't have holes in them, and the float lines are almost new. Most of the pots look like they haven't even been used two seasons-they are not battered and have no patches in their netting.

"I made these crab pots a couple of winters ago to build things up a little bit. I was just eeling before that, but I thought I'd try crabbing to spread out some. I was using the gill nets to catch shad for bait, but I only did a little better last season than before, and this year was worse. July, bass boats ran over three of my gill nets and cut the float lines. Plus I was having to make two trips out a day-one for the pots, and one for the nets-so my gas bill was double and my motor's about done."

Charlie smokes a cigarette as he listens to Jo's story. He has heard similar tales from many people over the years, but he nods sympathetically all the same. He stamps out his cigarette stub. "What do you want for the pots?"

"I'll take three dollars apiece for the crab pots and two dollars and a half for the eel pots."

Charlie looks the pots over. "All right," he says. "I'll think about it."

Gerry has been tossing a stick in the water for Bullitt to fetch, so now the dog is streaming with water and panting hard, his tongue flapping out. Charlie makes Bullitt ride in the truck bed on the way back to Tidewater. Riding with a wet dog is all right when it is just the two of them, but three up front makes it uncomfortable. As they ride along, Charlie asks Gerry what he thinks of the equipment. Gerry allows it looked pretty good to him, and Charlie agrees. They both decide the price is too high, but if Jo will come down to two-fifty that would be reasonable. They figure they'll stop by again in a week and offer him two dollars. Charlie doesn't expect there will be many buyers this late into the season. There is no rush.

Charlie drops Gerry off at his house and then stops at the bait dealer, several hundred yards down the main road. Bill Casey has lived in Tidewater for only four years. He moved from a big city in Virginia because he likes the water and because the cost of living is low out in the swamp country. He had always come down to Tidewater to hunt and fish, so when he saw a parcel of land suitable for a trailer he leased it, moved down, and rented out his house in Virginia. For most of the day he works as a home handyman, while his wife, 
Libby, takes care of the bait business. She makes no secret of her dislike for Tidewater and escapes to her old friends in Virginia on most weekends. She was active in the Ladies Auxiliary and the Women's Missionary Society back home but cannot seem to make the same kind of friends in the church in Tidewater. She went to church regularly when she first moved down. Now she has rejoined her former church and rarely attends the Tidewater church.

Bill Casey runs his bait business out of a refrigerated tractor trailer behind his house trailer. Charlie drives his truck up beside the tractor trailer and sees Bill sitting in a folding chair there in the shade. Most days when Charlie comes by there are three or four crabbers buying bait, but today he is late again and he is the only one there. "Running a little late again, ain't you, Charlie?" remarks Bill.

"Yeah. Frozen bait slowed me down."

Bill raises his eyebrows. "If I were you I'd keep it where it could thaw out better."

"Yeah, I guess I ought to. What you got left?"

Bill has three baskets of spots and croakers, and the rest are frozen fat backs. Charlie takes the three and makes it up with two baskets of fat backs. At least if they are still frozen tomorrow, he can start with the spots and croakers, and he won't have to worry about running out of bait.

As Charlie loads up the bait Bullitt sniffs at the baskets. Charlie whistles him down from the truck bed and opens the passenger door for him. Bill comes out of the trailer with the pink carbon copy of the bait invoice. Charlie gets into the cab and puts the invoice in a clip on the right-hand side of the sun visor without reading it. He knows what it says_-“5 Bushels Bait @ \$4. TotaL \$20.” He will settle up with Bill when Sam pays him off at the end of the week.

There is not much time before supper, but Charlie decides he has a few minutes to spare and heads off down the swamp road. As soon as he has left town, he pulls off the road and takes his fly rod from the gun rack in the back of the cab, warning Bullitt to stay inside. He stands on the brink of the drainage ditch and makes a long, high arcing cast at a diagonal to the bank. Just before the spinner reaches the far bank he releases the thumb lock on the reel, and the bailer snaps in place, ending the cast and causing the spinner to plop down in the water. Charlie reels in slowly with his rod held horizontally forward. When the spinner is just about to the near bank, he lifts the tip of the rod, jerking the spinner out of the water, and casts again.

After fifteen casts he decides he will cast five more times. After five more, he casts once more for luck and then once again. He puts the 
rod back in the gun rack and lets Bullitt out. He finds a stick and throws it as far as he can into the ditch. Bullitt splashes into the water and swims after the stick. He mouths it gently, swims to the bank, and runs back to where Charlie is standing. He drops the stick at Charlie's feet and sits, waiting for him to throw it again. Charlie keeps the game up for ten minutes or so. Bullitt is a good retriever and likes the water. Charlie tries to keep him in shape all through the year. In the winter he earns his keep retrieving ducks, but he has to have some exercise in the summer too. Some dogs get lazy and won't retrieve at all if they are not kept in practice.

Charlie sits down on the bank to smoke a cigarette, and Bullitt runs up and down the bank snuffling in the weeds. The sun lies low over the swamp grasses and is beginning to turn blinding red. Occasional puffs of air rustle the grasses and then die out. The cigarette smoke keeps some of the insects at bay, but soon they are brave enough to withstand it and they swarm around Charlie's head and arms. When he gets tired of swatting them he calls Bullitt, and they head back to Tidewater, to Charlie's mother's house.

Charlie's mother lives in a house on the main road near the center of town. It was built in $\mathbf{1 8 6 8}$ by her grandfather, Cull Kinsey, and added onto, up and out, by him and later generations. Charlie enters the house by the front door and turns right, toward the kitchen, with Bullitt close behind. On his way he checks the mail on the telephone stand. He uses his mother's post office box for convenience. He cannot always check the post office during the day, and anyway he doesn't get much mail. Today there is nothing addressed to him. Charlie's mother sits at the kitchen table, her arms folded on her bosom, staring out the window. Whenever she is working or taking a rest, she sits at one of the front windows, watching the road. She was born in this house and has lived in it all her life. Everything that has happened to her, almost, has come down that road.

Charlie's sister Jean Anne is working in the kitchen, finishing up supper under her mother's supervision. She sets the table with a knife, fork, shallow bowl, and plate at each of six places and tears off paper towels from a roll for napkins. Charlie grabs a can of dog food from the pantry at the back of the kitchen, opens it and dumps it out into one of two plastic bowls by the back door, then fills the other bowl with water. Bullitt chews down the meaty mush and then laps his water bowl dry. Charlie refills it. Jean Anne is standing at the stove keeping an eye on the pots when her husband, Frank, comes in. Charlie and Frank sit down at the table, their backs to the stove, facing the front window. Jean Anne mixes a jug of instant iced tea and 
carries it to the table. Then she goes back to the stove to begin dishing up.

She spoons cornmeal dumplings from the top of the greens pot, where they have been steaming for the last hour, and arranges them on a large flat plate. Then she ladles the boiled greens into a deep, round dish, making sure that a good quantity of the pot liquor comes with them. She makes a wreath of boiled potatoes around the edge of the bowl and then fishes down into the green water in the pot for the lump of salt pork, which she places on top of it all. Adding a few more spoons of pot liquor for good measure, she places the dish of greens and dumplings in the center of the table. At this point Gerry and his younger brother, Willie, come in and sit opposite the men with their backs to the window. Mary explains to the table in general, and Charlie in particular, that Marvin Hayman, the superintendent of the Sunday School, had brought the greens over this morning. He had said he might have some work for Charlie if he wanted it, and she had told him he could probably catch him at the store tonight. She tells him she expects it has something to do with the foundation of the new preacher's house, and Charlie nods. He knows exactly what it is.

Jean Anne scoops the last three bluefish fillets out of the grease in a castiron skillet on the stove on to a plate of already cooked fish that have been keeping warm in the oven. They are nubbly and brown with a cornmeal breading. She hands the plate to her mother. She is about to sit down at her place at the foot of the table when she asks her mother if there is anything else to do. Mary says her friend Margaret across the street is doing more and more poorly, and it would probably be good to send her a bowl of greens. Jean Anne gets out a clean bowl and makes up another mess of greens and potatoes, this time without the salt pork. She covers the dish with a tea towel and carries it out the back door.

Mary takes a piece of fish and passes the dish on to Charlie, who does the same. She spoons two potatoes on to her plate and a pile of greens into her dish. She reaches down beside her for a bag that contains white onions and pulls out a large one. With a paring knife from the counter behind her she peels the onion, crosshatches it a third of the way through, and slices the dice on top of her greens. She passes the onion and knife to Charlie and reaches for the vinegar bottle to pour over the onions. Charlie dresses his greens in the same way and places onion and knife between himself and his mother. $\mathrm{He}$ knows the others at the table will not take raw onions, but he may have more.

Jean Anne gets to the table just as all plates are filled. Mary asks her 
to say grace, and she quickly recites "For these and all blessings, Lord, let us be thankful, Amen." The men pass all of the food dishes down to Jean Anne, and everyone sets to eating in silence. Charlie and Frank eat quickly and soon take second helpings of everything. The women and boys eat slower, the women taking small extra helpings of greens and fish. Mary offers Charlie and Frank more of all the dishes in turn. Frank refuses, Charlie takes a very small spoonful of greens.

As they are finishing, Jean Anne gets up and puts a full kettle of water on the stove to boil. The boys ask to be excused, and the men slide their chairs back from the table. Jean Anne clears the plates from the table, scraping the scraps into a basket under the sink. Bullitt bustles around her. Sometimes he gets the table scraps, but today there may be fish bones in them. To make up, she scoops a small piece of fish from the table and throws it at his muzzle. Meanwhile the kettle whistles, and she pours out four cups of instant coffee.

Over coffee, Jean Anne asks Charlie, "Did you all get to see them crab pots?"

"Yeah, they seemed all right. If he'll come down on the price some, Gerry ought to go ahead and get 'em."

Frank has been listening as he drinks the hot coffee. "What's he asking for 'em?' he asks now.

"Three dollars apiece. But he'd probably take two dollars and a half."

The men lapse into silence. Mary asks Jean Anne, "How's Miss Margaret making out?"

"She says she's been in bed all day. She looked poorly to me."

"Well, she sure has suffered," says Mary.

"Yes, she sure has," Jean Anne agrees. "It's real hard on the family when the cook is sick."

Coffee over, Jean Anne gets up to wash dishes. Frank moves into the living room, sits down on the couch, and looks over the evening paper. Charlie calls Bullitt, who has slumped on the floor, and leaves by the front door.

It's a short ride to the general store. Charlie pulls into the parking lot-paved with gravel and crushed bottle caps. On a bench by the door two men sit looking straight ahead. One of them is short and lean. He is V. B. Griggs, the store owner and a good friend of Charlie's: they go hunting together in the winter and fish when they can in the summer. The other man is stout with grey whiskers. He is Roy Midyett, an old-time fisherman who still looks after his nets every day. He plays Santa Claus at the annual church Christmas party, and he still reminds Charlie of Santa without the costume-even more so 
tonight because he is wearing red pants and a red checkered shirt. Roy hardly ever misses a night at the store, and Charlie is always glad to see him. He can tell stories nonstop that make you laugh and laugh.

V. B. stands up when he sees Charlie, insisting that Charlie take his own seat since he has to be up and down anyway to pump gas. Charlie sits down beside Roy, and Bullitt sniffs around the side of the buildings where the garbage cans are. V. B. walks off to pump gas for a blue sedan that has just pulled in. When he comes back, he leans against a freezer containing bags of ice and folds his arms. The left side of his face is lumpy and distorted: he has an enormous plug of tobacco in his cheek. No one likes to chew more than V. B. He takes his plug out only to eat and sleep, and Charlie has even caught him napping with it in his mouth.

The three men drift into a conversation about the heat and the yellow flies, and they all have a good laugh at V. B.'s story about the Zuzu flies and the state trooper. V. B. leaves again to pump gas and ends up taking care of three in a row. Meanwhile, three more men join the group at the bench: Mike Branch the barber, "Bub" Saunders and Bob Fulcher, fishermen. Roy is beginning to warm up, and soon everyone is hooting over his story about the troubles a friend of his had with a cottonmouth that wanted to get into his skiff. It reminds Charlie of the day last deer season when he was poling V. B. from one stand to another along a drainage ditch and killed eleven cottonmouths in the water with his pole.

As Roy starts in on the story of a friend who was bitten by a cottonmouth, Charlie sees Marvin Hayman, the Sunday School superintendent, drive up. Marvin is a farmer and almost never comes down to the store at night. Charlie knows Marvin has come especially to see him, so he eases himself away from the group of storytellers and goes over to greet him. The two men go inside the store. Each pulls a bottle of cola from the drink cooler, and they sit down on a bench by the store window.

Marvin explains they've had a hard time keeping the building of the new preacher's house going. They were hoping to do most of the construction using volunteer labor, but they've had trouble with some of the skilled jobs. They've dug and poured the footings but haven't found anyone yet to lay the block foundation. He knows Charlie doesn't have the time to volunteer. Marvin will pay him if he wants the job.

What he doesn't say is that getting the money to pay skilled workers has caused a crisis in the church. It had taken years of bake sales, chicken suppers, October sales, and special collections to save the 
money to buy the materials for the house. Inflation kept eating away the buying power of their savings each time they thought they were ready to build. A few younger members had suggested floating a loan to get things started, but this idea was quickly squashed. In its hundred-year history the church had never once been in debt, and many of the older members of the church had never held loans. The church had been built with donated materials and volunteer labor, and the old preacher's house had been bought through fund raisers. Borrowing seemed an admission of defeat. But volunteer labor was scarce and county building codes required expert interpretation, so some people had to be hired. The building fund was dry. Marvin realized they would have to take out a loan, like it or not. He had spent nights visiting executive officers and church leaders, bringing them around. Last Sunday after worship service he called an extraordinary business meeting and put the matter up for vote. Before the decision he had several key members testify their support. The motion passed unanimously, and Marvin was sent out to hire workers.

Charlie had learned the trade of mason not long after he was married. He had fished with one of his uncles since he left high school, but married life wasn't easy when a man couldn't count on his profits from one day to the next. He had apprenticed with a mason in a city forty miles away. Once he'd learned his trade, he was working jobs in towns over a wide radius. Sometimes he had to stay over on week nights, only coming home weekends. He had been married fifteen years when his wife died suddenly. He kept up masonry for two years after her death and then little by little began to take up fishing again. At first he just helped out with the winter haul seining and set a few gill nets. The break came the following spring, when he set a line of crab pots. Tending crab pots cuts out other occupations. He still takes out his masonry tools to do odd jobs around Tidewater when he is desperate for cash.

He tells Marvin he will think about the job. Charlie will have to give this matter some serious thought. He can't give up crabbing now for fear of losing good money while the prices are holding. And if he quits now for a week, Sam Smith probably won't take him back. All dealers want regular workers. On the other hand he has a personal obligation to the church. His great grandfather donated the land on which the church is built and was a charter member. His mother is president of the women's Bible class, his sister is church secretary, and her husband is a deacon. If the church could hold off on the construction a few more weeks, he might be able to take care of both commitments.

Charlie goes back outside to find that Roy is in the middle of a story 
about a wildcat. He sits down to catch the end of it. Bub and Mike have gone home, and a group of boys, including Charlie's two nephews, are lounging by the ice freezer, half taking in the stories. Tales continue as the dark thickens. Finally the strong light from the store front draws too many bugs and forces the men inside.

Charlies uses the move as an excuse to get going. He pulls a can of two-stroke oil from the shelf, goes out, and drives his truck up to the pumps. He pumps the gas himself. While his truck fills, he empties the can of oil into the gas can in back. Then he fills his can, screwing the truck's gas cap on at the same time. Inside the store V. B.'s daughter, Lisa, is at the register. He flips her a quarter for the cola and tells her he has bought a can of two-stroke oil and ten dollars' worth of gas. She pulls a box of invoice books toward her and finds the one marked with Charlie's name. Charlie pulls a pack of cigarettes from the rack beside her and puts it on the counter. She writes up the invoice. He signs it, pockets the cigarettes, turns to the knot of men in the corner, says goodnight, and walks to his truck. Bullitt is sniffing the tires, waiting for him, and Charlie holds open the door for him to jump in.

The swamp road is pitch dark on the way home. The truck headlights light the column of road between the fields of swamp grasses. Once he sees a pair of dull orange points of light close to the road: a possum, probably. Frogs hop and glitter across his path. About a mile from home the music on the radio ends, the DJ announces it is 9:30, and gives the bottom-of-the-hour weather forecast. Overnight lows in the seventies, clear, mild, and humid. Tomorrow hazy, hot, and humid, highs in the low nineties, zero percent chance of rain. Extended forecast: more of the same.

Charlie pulls into his driveway and backs up to his shed. He puts the bait baskets away, then drives the truck to his back door. He takes his water bottle with him as he gets out of the cab. He pushes open the screen door and goes into the house, Bullitt right behind him. In the kitchen he turns on the cold tap, lets it run until the water is good and cold, fills up the bottle, puts it in the refrigerator. It's too hot to go to bed right away. He'll sit outside on the back step for one last cigarette. The stars are shining clear and hard. There is no breeze. Katydids argue endlessly; cicadas, spring peepers, and bullfrogs add to the din. Charlie thinks back over the day; uneventful. That suits him fine. 